\title{
Efektivitas Penggunaan Media Busy Book dalam Meningkatkan Life Skill pada Anak Usia 3-4 Tahun di Playgroup X
}

\author{
Siti Jenab*, Dinar Nur Inten \\ Prodi Pendidikan Guru PAUD, Fakultas Tarbiyah dan Keguruan, Universitas \\ Islam Bandung, Indonesia. \\ *s.jenab03@gmail.com, dinar.nurinten@gmail.com
}

\begin{abstract}
This research is motivated by the problems found in the field, namely there are still many children who have not been able to take care of themselves properly, such as buttoning clothes, wearing shoes and brushing teeth. This is evident when completing activities children are still dependent and assisted by parents and teachers while at school. The purpose of this study is to prove the effectiveness of using busy book media in improving life skills for children aged 3-4 years in Playgroup X. This study uses the Pre-experimental method with the type of One Group Pre-Test Post-Test Design. At the pre-test stage, the researchers conducted initial observations to determine the initial abilities of life skills in children aged 3-4 years at the Smart Kindergarten Playgroup before being given treatment, the next stage was to give treatment to children during learning activities using busy book media, the last stage was the post-test stage. The test was conducted to determine the ability of the end of life skills in children aged 3-4 years in Playgroup $\mathrm{X}$ after being given treatment. The results of this study showed that most children experienced an increase after being given treatment using a busy book, indicating that the ability to button clothes was that there were no children who had not yet developed, $35.4 \%$ of children began to develop, $31.3 \%$ of children developed as expected, and 33, $3 \%$ of children are developing very well. In the ability to wear shoes, there are $3.0 \%$ of children who have not developed, $25.0 \%$ of children who are starting to develop, $28.0 \%$ of children who develop as expected, and $44.0 \%$ of children who develop very well. In the ability to brush their teeth there are $2.0 \%$ of children who have not developed, $20.0 \%$ of children who are starting to develop, $43.0 \%$ of children who develop as expected, and $35.0 \%$ of children who develop very well. proven through the Paired Sample T-Test test, namely ( $\mathrm{p}=$ $0.001<0.005$ ) which means Ho is rejected and Ha is accepted, so it can be concluded that busy book media is effective for improving life skills in children aged 3-4 years in the Smart Kindergarten playgroup.
\end{abstract}

Keywords: Effectiveness, Media Busy Book, Life Skill, Early Childhood..

\begin{abstract}
Abstrak. Penelitian ini dilatar belakangi oleh permasalahan yang ditemukan pada saat dilapangan yaitu masih banyaknya anak yang belum mampu dalam mengurus dirinya sendiri dengan baik, seperti mengancingkan baju, memakai sepatu dan menggosok gigi. Hal ini terbukti ketika menyelesaikan aktivitas anak masih bergantung dan dibantu oleh orang tua maupun guru ketika di sekolah. Tujuan dari penelitian ini yaitu membuktikan efektivitas penggunaan media busy book dalam meningkatkan life skill pada anak usia 3-4 tahun di Playgroup X. Penelitian ini menggunakan metode Pre-eksperimen dengan jenis One Group Pre-Test PostTest Design. Pada tahap pre-test peneliti melakukan observasi awal untuk mengetahui kemampuan awal life skiil pada anak usia 3-4 tahun di Playgroup X sebelum diberikan treatment, tahap selanjutnya yaitu memberikan treatment pada anak saat kegiatan pembelajaran menggunakan media busy book, terakhir yaitu tahap post-test dilakukan untuk mengetahui kemampuan akhir life skill pada anak usia 3-4 tahun di Playgroup $\mathrm{X}$ setelah diberikan treatment. Hasil dari penelitian ini menunjukkan bahwa sebagian besar anak mengalami peningkatan setelah diberikan treatment menggunakan busy book menunjukkan bahwa kemampuan mengancingkan baju yaitu tidak ada anak yang belum berkembang, 35,4\% anak mulai berkembang, 31,3\% anak berkembang sesuai harapan, dan $33,3 \%$ anak berkembang sangat baik. Pada kemampuan memakai sepatu terdapat 3,0\% anak yang belum berkembang, 25,0\% anak yang mulai berkembang, 28,0\% anak yang berkembang sesuai harapan, dan 44,0\% anak berkembang sangat baik. Pada kemampuan menggosok gigi terdapat 2,0\% anak yang belum berkembang, 20,0\% anak yang mulai berkembang, 43,0\% anak yang berkembang sesuai harapan, dan $35,0 \%$ anak yang berkembang sangat baik.serta adanya perbedaan yang signifikan setelah dibuktikan melalui uji Paired Sample T-Test yaitu $(\mathrm{p}=0,001<0,005)$ yang artinya Ho ditolak dan Ha diterima, sehingga dapat disimpulkan bahwa media busy book efektif untuk meningkatkan life skill pada anak usia 3-4 tahun di Playgroup X.
\end{abstract}

Kata Kunci: Efektivitas, Media Busy Book, Life Skill, Anak Usia Dini. 


\section{A. Pendahuluan}

Anak usia dini yaitu setiap individu yang akan memasuki awal kehidupan serta mengalami proses pertumbuhan dan perkembangan dengan sangat cepat, sebab anak sedang menjalani periode keemasan (golden age). Agar setiap perkembangan pada nilai agama moral, motorik halus dan kasar, kognitif, bahasa, sosialemosional, serta kemandirian yang dimilikinya berkembang dengan optimal, anak membutuhkan stimulus yang dapat dilakukan melalui proses pendidikan (Masnipal, 2018). Sebagaimana terkandung dalam Undang-Undang Republik Indonesia No 20 Tentang Sistem Pendidikan Nasional, 2003 Bab 1, Pasal 1 ayat 14, yang menyatakan bahwa:

"Pendidikan anak usia dini adalah usaha untuk membina anak dimulai dari ia lahir sampai berusia enam tahun seraya memberikan dorongan untuk menstimulus pertumbuhan dan perkembangan jasmani dan rohani supaya anak memiliki kesiapan dalam menempuh jenjang pendidikan selanjutnya".

Pentingnya dalam mendidik anak telah diterangkan dalam Al-Qur'an (QS. Lukman Ayat 13):

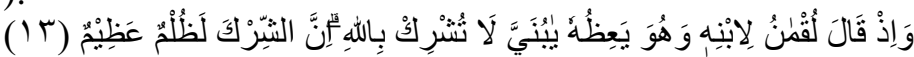

Artinya: "Dan (ingatlah) ketika Luqman berkata kepada anaknya, di waktu ia memberi pelajaran kepadanya, "Wahai Anakku! Janganlah kamu mempersekutukan Allah, sesungguhnya mempersekutukan (Allah) adalah benar-benar kezaliman yang besar”.

Pengetahuan untuk menstimulasi setiap tumbuh kembang anak harus di pahami dan dikuasai dengan baik serta mempersiapkan berbagai strategi dalam membimbing dan merawat anak agar setiap tahap perkembangannya dapat berkembangan dengan optimal.

Agar kemampuan anak tercapai dengan optimal, selain bekal kemampuan akademis peserta didik juga harus dibekali dengan keterampilan kecakapan hidup atau life skill.

Menurut World Health Organization dalam Life Skills Education For Children and Adolescents In Schools (1997),

"Life skills are abilities for adaptive and positive behaviour, that enable individuals to deal effectively with the demands and challenges of everyday life"

Sedangkan menurut Anwar (2015) life skill ialah kemampuan setiap individu untuk menyesuaikan dan berkomunikasi dengan orang lain maupun masyarakat sekitar seperti keterampilan dalam mengambil suatu keputusan, dapat berkomunikasi dengan efektif, menjalin hubungan yang baik dengan orang lain, menumbuhkan kesadaran diri, empati, serta dapat mengendalikan emosi yang merupakan bagian dari pendidikan. Anak mulai diarahkan pada dasar-dasar kecakapan hidup seperti kemandirian atau kemampuan menolong dirinya tanpa bantuan oranglain serta berlatih untuk melakukan aktivitas atau keterampilan yang dapat diterapkan dalam kehidupan yaitu meliputi keterampilan motorik halus yang terdiri dari perawatan diri, peduli lingkungan, serta sopan santun, dalam Montessori disebut sebagai aktivitas praktik kehidupan atau Practical Life Activities (Zahira, 2019).

Adapun penelitian relevan yang telah dilakukan oleh Nina Kurniawati, Tuti Hayati (2020) yang berjudul "Meningkatkan Kemandirian Anak Melalui Kegiatan Practical Life Skill" penelitian ini bertujuan untuk mengetahui cara meningkatkan perilaku mandiri pada anak dengan menerapkan aktivitas practical life skill. Hasil dari penelitian menunjukkan perilaku mandiri anak sebelum dibiasakan aktivitas practical life skill sangat kurang dengan perolehan nilai 44,76\%, dan menunjukkan peningkatan setelah lakukan pembiasaan kegiatan practical life skill dalam meningkatkan kemandirian anak. Kemandirian anak pada aktivitas practical life skill pada siklus I yaitu dengan kriteria kurang dengan perolehan nilai 55,94\%, pada siklus II dengan kriteria baik karena nilai yang diperoleh rata-rata 75,35. Hipotesis dalam penelitian ini diterima, maka kegiatan dalam penerapkan practical life skill dalam meningkatkan kemandirian pada anak.

Relevansi dengan penelitian ini yaitu meneliti mengenai life skill pada anak, sedangkan letak perbedaannya yaitu peneliti ingin mengetahui efektivitas penggunaan media busy book dalam meningkatkan life skill anak, kegiatan life skill yang akan diteliti yaitu kemampuan mengancingkan baju, memakai sepatu dan menggosok gigi pada anak usia 3-4 tahun. Sedangkan peneliti terdahulu menerapkan kegiatan practical life skill dalam mengembangkan perilaku 
mandiri anak.

Dalam mengaplikasikan life skill di lembaga pendidikan usia dini dapat menggunakan media agar memudahkan peserta didik mendapatkan suatu pengetahuan yang abstrak menjadi lebih konkrit serta mendapatkan pengalaman yang bermakna (Sari, 2013). Oleh karena itu, agar terciptanya kondisi yang efektif dalam merangsang kemampuan atau keterampilan anak maka diperlukan media.

Media ialah benda maupun makhluk hidup yang dimanfaatkan untuk menyampaikan pesan atau informasi (Fadlillah, 2017). Sebagaimana hasil penelitian (Permatasari et al., 2018) bahwasannya pada saat memperkenalkan astronomi pada anak usia dini akan jauh lebih membuat anak tertarik dan senang jika menggunakan media, misalnya dengan memanfaatkan media Big Book. Sedangkan media yang digunakan untuk mengaplikasikan life skill dalam penelitian ini yaitu busy book. Busy book merupakan buku berbahan kain flanel yang terbagi menjadi sampul buku dan berbagai aktivitas serta dibuat sesuai kebutuhan proses pembelajaran yang akan diperkenalkan kepada anak (Nilmayani et al., 2017). Busy book berbahan kain flanel berwarna terang yang meliputi halaman sampul dan berbagai aktivitas bermain menyenangkan untuk anak yang disesuaikan dengan tema pembelajaran dan dapat mengingkatkan keterampilan anak dalam membina dirinya (Yulianto, 2018). Busy book yang digunakan sebagai media pembelajaran untuk anak memiliki manfaat untuk melatih kreativitas atau imajinasi anak, menstimulasi rasa ingin tahu dengan cara yang menyenangkan, melatih kemampuan motorik halus, keterampilan serta perkembangan sosialemosional pada anak (Kreasiumy, 2016). Media busy book yang digunakan untuk kegiatan pembelajaran anak terdapat berbagai permainan unik yang dapat mengembangkan keterampilan anak seperti kegiatan perawatan diri misalnya mengancingkan baju, mengenal konsep berhitung atau mengenal ukuran. Hal tersebut dapat ditujukan dalam mengembangkan perkembangan anak melalui salah satu kegiatan yang lebih dominan (Annisa, 2016).

Hasil penelitian relevan yang telah dilakukan oleh Nurul Ezkanandyta (2019) yang berjudul "Efektivitas Penggunaan Alat Permainan Edukatif Busy Book Terhadap Kecerdasan Logika Matematika Anak Usia Dini (Penelitian Kuasi Eksperimen Pada Kelompok B)". Tujuan dari penelitian ini adalah untuk mengidentifikasi apakah permainan edukatif busy book efektif dalam meningkatkan kecerdasan logika matematika anak usia dini. Hasil yang diperoleh yaitu sebesar $0,005<0,05$ menunjukkan bahwa setelah diberikan treatment terdapat peningkatan signifikan, sehingga alat permainan edukatif busy book efektif digunakan dalam mengembangkan kecerdasan logika matematika anak usia dini.

Relevansi dengan penelitian ini yaitu meneliti mengenai penggunaan media busy book, sedangkan letak perbedaannya yaitu peneliti akan meneliti terkait life skill atau keterampilan kecakapan hidup pada anak usia 3-4 tahun sedangkan peneliti terdahulu meneliti kecerdasan logika matematika pada anak usia dini.

Kegiatan untuk melatih life skill anak menggunakan media busy book maka anak mendapatkan stimulus dari guru, sehingga secara tidak langsung melatih anak untuk berperan aktif dalam kehidupannya sehari-hari. Kegiatan tersebut dapat melatih kemandirian anak, konsentrasi, fokus, koordinasi serta menstimulasi kekuatan tiga jari sebagai persiapan untuk menulis (Wijaya, 2020). Keterampilan yang diteliti dalam penelitian ini yaitu terdiri dari mengancingkan baju, memakai sepatu serta menggosok gigi. Selain itu juga orangtua dapat melakukannya di rumah karena anak akan merasa senang dan keterlibatan orangtua dapat mempererat komunikasi anak dengan ibu maupun ayah untuk menstimulus perkembangan kognitif serta sosialemosional anak (Inten et al., 2021).

Berdasarkan dari uraian latar belakang diatas, maka rumusan masalah dalam penelitian ini yaitu: "Adakah peningkatan life skill pada anak usia 3-4 tahun setelah treatment penggunaan media busy book di Playgroup X?". Adapun tujuan dalam penelitian ini yaitu:

1. Untuk mengidentifikasi life skill pada anak usia 3-4 tahun sebelum menggunakan media busy book di Playgroup X.

2. Untuk mengidentifikasi life skill pada anak usia 3-4 tahun sesudah menggunakan media busy book di Playgroup X.

3. Untuk mengidentifikasi adakah peningkatan life skill pada anak usia 3-4 tahun setelah 
treatment penggunaaan media busy book di Playgroup X.

\section{B. Metodologi}

Pendekatan dalam penelitian ini yaitu pendekatan kuantitatif, cara pengumpulan datanya berupa angka (numerical data) berdasarkan tingkah laku yang diamati dari sampel yang selanjutnya diolah dengan analisis berbentuk angka (Setyosari, 2013). Metode penelititiannya menggunakan metode pre eksperimen karena adanya keterbatasan jumlah sampel dalam penelitian, dengan menggunakan one group pre-test post-test design, yaitu satu kelompok eksperimen diukur pretest, kemudian diberikan treatment, serta di ukur post-test tanpa ada kelompok pembanding. Desain ini digunakan dengan tujuan yang ingin dicapai yaitu untuk mengidentifikasi efektivitas penggunaan media busy book dalam meningkatkan life skill pada anak usia 3-4 tahun di Playgroup X yang berjumlah 12 anak dalam satu kelas.

Adapun desain penelitian ini yaitu:

Tabel 1. Desain Penelitian

\begin{tabular}{|c|c|c|c|}
\hline Kelompok & Pre test & Treatment & Post test \\
\hline Eksperimen & O1 & X & O2 \\
\hline
\end{tabular}

(Sugiyono, 2016)

Keterangan:

O1 : Sebelum diberikan treatment (Pre-test)

$\mathrm{O} 2$ : Setelah diberikan treatment (Post-test)

$\mathrm{X}$ : Treatment (penggunaan media busy book) unjuk kerja.

Teknik pengumpulan data dalam penelitian ini yaitu: observasi, dokumentasi, serta

Sedangkan teknik analisis datanya yaitu: 1) menentukan skor maksimal, skor minimal, rentang skor serta interval skor, 2) Uji normalitas Shapiro wilk (p>0,05), 3) Uji hipotesis Paired Sample T Test.

\section{Hasil dan Pembahasan}

\section{Life Skill Pada Anak Usia 3-4 Tahun Di Playgroup X Sebelum Menggunakan Media Busy Book}

Peneliti memperoleh hasil pada setiap kemampuan anak yaitu: pada kemampuan mengancingkan baju terdapat 37,5\% yang belum berkembang, 52,1\% yang mulai berkembang, $10,4 \%$ yang berkembang sesuai harapan dan tidak ada yang berkembang sangat baik. Pada kemampuan memakai sepatu terdapat 33,3\% anak yang belum berkembang, 52,8\% anak yang mulai berkembang, $11,1 \%$ anak yang berkembang sesuai harapan, dan 2,8\% anak yang berkembang sangat baik. Pada kemampuan menggosok gigi terdapat $45,0 \%$ anak yang belum berkembang, 47,2\% anak yang mulai berkembang, 8,3\%\% anak yang berkembang sangat baik, dan tidak ada anak yang berkembang sangat baik. Dari hasil tersebut dapat disimpulkan dari 12 orang anak terdapat 9 anak yang belum berkembang, 3 anak yang mulai berkembang dan tidak satu pun yang berkembang sangat baik atau berkembang sesuai harapan.

Agar kemampuan life skill anak berkembang dengan optimal, maka dilakukan treatment menggunakan media busy book. Hal ini sesuai dengan tujuan pendidikan life skill adalah untuk mempersiapkan anak dengan baik secara akademik maupun sosialemosional untuk membentuk kepribadian anak menjadi pribadi bertanggungjawab yang dapat menemukan solusi dalam menghadapi setiap permasalahan dalam kehidupannya (Muhsyanur \& Primarni, 2018). Adapun tujuan pendidikan life skill menurut Anwar (2015) yaitu untuk mengaktualisasikan kemampuan peserta didik dalam menghadapi masalah, kesemptan bagi kepala sekolah dalam mengembangkan pembelajaran yang fleksibel, untuk mengoptimalkan pemanfaatan sumber daya yang terdapat dilingkungan sekitar. 
Life Skill Pada Anak Usia 3-4 Tahun Di Playgroup X Setelah Menggunakan Media Busy Book Pada tahap ini peneliti memberikan treatment pada anak usai 3-4 tahun di Playgroup X dengan menggunakan media busy book. Busy book merupakan buku yang di dalamnya terdapat macammacam kegiatan bermain yang terbuat dari kain flanel dan di desain untuk anak usia dini (Mufliharsi, 2017). Busy book berbahan kain flanel berwarna terang terdiri dari bagian sampul dan berbagai aktivitas bermain menyenangkan untuk anak yang disesuaikan dengan tema pembelajaran dan dapat mengingkatkan keterampilan anak dalam membina dirinya (Yulianto, 2018). Keterampilan yang diteliti yaitu mengenai life skill anak usia 3-4 tahun di Playgroup X yang terdiri dari mengancingkan baju, memakai sepatu serta menggosok gigi.

Berikut ini beberapa aktivitas menggunakan media busy book yang digunakan dalam mengembangkan life skill pada anak usia dini diantaranya yaitu:

1. Mengancingkan Baju

Membiasakan anak untuk mandiri harus dilatih sejak dini yang berguna untuk melatih kemandiriannya, salah satu kegiatan yang dapat dilakukan yaitu membuka dan memasukkan kancing baju sendiri. Dalam media busy book terdapat kegiatan mengancingkan baju yang berguna untuk melatih anak mengancingkan baju yang dibuat dengan dua kain yang disambungkan dengan dua sampai tiga kancing besar, lubang kancing vertikal seperti mengancing baju ketika berpakaian. Hal ini dapat dilakukan dengan cara guru duduk di samping anak, kemudian menunjukkan setiap gerakan jari secara perlahan tahapan demi tahapan sehingga anak dapat mengamatinya dengan jelas dan seksama. Gerakan pertama yaitu menyesuaikan dua potongan kain sampai kedua ujungnya dapat disatukan, pegang kancing dan lubang kancing dengan kedua tangan lalu masukkan dari atas sampai bawah, terakhir rapikan sampai kancing terpasang sempurna (Montessori, 2020).

2. Memakai Sepatu

Bagi anak memakai sepatu sendiri merupakan suatu tantangan yang cukup menyulitkan, memerluka kesabaran serta latihan untuk melatih anak melakukan memakai sepatunya sendiri. Maka dari itu, dalam meningkatkan life skill pada anak untuk memakai sepatu libatkan lebih banyak langkah atau perintah yang harus anak ikuti seperti menunjukkan kepada anak cara memasukkan kaki kedalam sepatu, lalu cara memasukkan velcro serta belajar menarik velcro sepatu untuk mengencangkannya. Kemudian, mereka dapat mengenakan sepatu mereka sepenuhnya tanpa bantuan oranglain (Davies, 2020).

3. Menggosok Gigi

Kebiasaan menggosok gigi merupakan kebiasaan sehat yang perlu dibiasakan untuk menjaga kebersihan mulut serta gigi pada anak. Bagi anak menggosok gigi bukanlah hal yang mudah, karena membutuhkan teknik tertentu agar gigi bersih dan sehat. Dalam mengembangkan life skill anak untuk membiasakan menggosok gigi sendiri dengan mengenalkan pentingnya menggosok gigi menggunakan media busy book.

Dari data hasil penelitian setelah diberikan treatment menggunakan busy book menunjukkan bahwa kemampuan mengancingkan baju yaitu tidak ada anak yang belum berkembang, 35,4\% anak mulai berkembang, 31,3\% anak berkembang sesuai harapan, dan $33,3 \%$ anak berkembang sangat baik. Pada kemampuan memakai sepatu terdapat 3,0\% anak yang belum berkembang, 25,0\% anak yang mulai berkembang, 28,0\% anak yang berkembang sesuai harapan, dan 44,0\% anak berkembang sangat baik. Pada kemampuan menggosok gigi terdapat 2,0\% anak yang belum berkembang, 20,0\% anak yang mulai berkembang, 43,0\% anak yang berkembang sesuai harapan, dan 35,0\% anak yang berkembang sangat baik. Dari hasil tersebut dapat disimpulkan dari 12 orang anak yaitu tidak ada anak yang belum berkembang, 3 orang anak berkembang sesuai harapan, 5 orang anak berkembang sangat baik, dan 4 orang anak berkembang sesuai harapan.

Sesuai dengan prinip perkembangan anak yaitu belajar teru-menerus, yang diawali dari memberi wawasan mengenai suatu hal, menjelajahi lingkungan, serta menciptakan suatu persepsi (Latif et al., 2013). Penelitian ini berlangsung dilakukan selama kurang lebih tiga hari secara terus menerus yang dapat membantu menstimulasi perkembangan anak.

Berdasarkan penelitian yang telah dilakukan oleh Islamiah Arta Utomo, M. Ramli, 
Furaidah (2018) yang berjudul "Penerapan Strategi Bermain Melalui Media Busy Book untuk Meningkatkan Fisik Motorik Halus Anak Usia Dini”. Tujuan dari penelitian ini yaitu meningkatkan kemampuan motorik halus anak dalam mengkoordinasikan mata dan tangan menggunakan media busy book. Hasil observasi menunjukkan adanya peningkatan pada kemampuan motorik halus anak, pada siklus I nilai yang diperoleh yaitu 50\% dan meningkat pada siklus II mencapai $100 \%$ setelah diterapkan strategi menggunakan media busy book yang dilakukan oleh guru sehingga memperoleh kemajuan dalam mengkoordinasikan mata dan tangan.

\section{Peningkatan Life Skill Pada Anak Usia 3-4 Tahun Di Playgroup Smart Kinergarten Sebelum Dan Sesudah Menggunakan Media Busy Book}

Dalam meningkatkan life skill anak usia 3-4 tahun di Playgroup X sebelum dan sesudah menggunakan media busy book data yang dihasilkan pada Uji Paired Sampel T Test diperoleh nilai signifikansi 0,001 , artinya terdapat perubahan yang cukup signifikan karena lebih besar dari 0,05. Hasil data yang telah di analisis dan uji hipotesis menunjukkan bahwa media busy book memiliki efektivitas dalam meningkatkan life skill anak usia 3-4 tahun di Playgroup X karena terdapat perbedaan yang signifikan sebelum dan setelah diberikan treatment menggunakan media busy book.

Pada masa awal anak-anak atau usia dua sampai enam tahun berada dalam fase perangsangan perkembangan fungsi seluruh aspek fisik dan keterampilan, keluesan gerak pada motorik kasar dan motorik halus serta mempunya dorongan untuk mandiri (Erhamwilda, 2018). Pada awal masa perkembangan anak adalah periode yang paling ideal untuk mengeksplorasi berbagai keterampilan. Hal tersebut dibuktikan dengan karakteristik anak yang senang mengulang-ngulang suatu aktivitas sampai terampil melakukannya dengan senang hati, sifat pemberani anak untuk mengeksplorasi lingkungan disekitarnya tanpa merasa takut akan merasa sakit atau diejek oleh teman sebayanya, anak mudah mempelajari hal baru dengan cepat karena fisiknya yang sangat luwes dan keterampilan yang miliki baru sedikit. Keterampilan dalam berpakaian dengan mandiri dimulai pada masa bayi dan kemajuan terbesar rata-rata pada usia 1,5 tahun dan 3,5 tahun (Hurlock, 1991). Kegiatan tersebut dapat melatih kemandirian anak, konsentrasi, fokus, koordinasi serta menstimulasi kekuatan tiga jari sebagai persiapan untuk menulis (Wijaya, 2020).

\section{Kesimpulan}

Berdasarkan hasil penelitian dan pengujian hipotesis terkait dengan penggunaan media busy book dalam meningkatkan life skill pada anak usia 3-4 tahun di Playgroup X dapat disimpulkan bahwa:

1. Life skill pada anak usia 3-4 tahun sebelum menggunakan media busy book di Playgroup $\mathrm{X}$ menunjukkan bahwa terdapat 9 anak berkriteria belum berkembang, sebanyak 3 anak berkriteria mulai berkembang dan tidak satupun anak yang berkriteria berkembang sangat baik maupun berkembang sesuai harapan, hal ini dibuktikan dari perolehan hasil pre-test yang peneliti lakukan sebelum diberikan treatment.

2. Life skill pada anak usia 3-4 tahun setelah menggunakan media busy book di Playgroup $\mathrm{X}$ menunjukkan bahwa tidak ada anak yang berkriteria belum berkembang, 3 anak berkriteria mulai berkembang, 5 anak berkriteria berkembang sangat baik dan 4 anak berkriteria berkembang sesuai harapan, hal ini dibuktikan dari perolehan hasil post-test yang telah dilakukan peneliti setelah diberikan treatment.

3. Berdasarkan data hasil pre-test dan post-test yang telah di analisis, dan pengujian Paired Sampel T-Test hasil yang diperoleh yaitu $(\mathrm{p}=0,001<0,05)$ yang berarti Ho ditolak dan Ha diterima, maka dapat disimpulkan bahwa penggunaan media busy book dapat meningkatkan life skill anak usia 3-4 tahun di Playgroup X.

\section{Acknowledge}

Dalam penulisan skripsi ini banyak pihak yang memberikan masukan-masukan dan saran yang bermanfaat, maka dari itu penulis sampaikan rasa terimakasih kepada Bapak Dr. Dedih Surana, M.Ag., dan Ibu Dinar Nur Inten, S.Pd., M.Pd selaku pembimbing yang selalu memberi motivasi 
dan masukan sehingga skripsi ini dapat diselesaikan. Fakultas Tarbiyah dan Keguruan Universitas Islam Bandung yang selalu memberi arahan dari awal penyusunan sampai selesai, serta lembaga Playgroup X yang telah mengizinkan peneliti untuk melaksanakan penelitian skripsi.

\section{Daftar Pustaka}

[1] Anwar. (2015). Pendidikan Kecakapan Hidup. Alfabeta.

[2] Erhamwilda. (2018). Psikologi Belajar Islam. Dilengkapi dengan Pendidikan Seks bagi Anak - anak Usia Dini (Edisi pert). Psikosain.

[3] Hurlock, E. B. (1991). Psikologi Perkembangan Suatu Pendekatan Sepanjang Rentang Kehidupan (kelima). Erlangga.

[4] Undang-Undang Republik Indonesia No 20 Tentang Sistem Pendidikan Nasional, Jakarta: Direktorat Pendidikan Menengah Umum 6 (2003). http://stpibinainsanmulia.ac.id/wp-content/uploads/2013/04/Lamp_2_UU20-2003Sisdiknas.doc

[5] Latif, M., Zukhairina, Zubaidah, R., \& Afandi, M. (2013). Orientasi Baru Pendidikan Anak Usia Dini Teori Dan Aplikasi. Kencana.

[6] Masnipal, M. (2018). Menjadi Guru PAUD Profesional. Remaja Rosda Karya.

[7] Mufliharsi, R. (2017). Pemanfaatan Busy Book Pada Kosakata Anak Usia Dini Di PAUD Swadaya PKK. Jurnal Universitas Indraprasta PGRI, V Nomor 2.

[8] Muhsyanur, \& Primarni, A. (2018). Kapita Selekta Pendidikan Menelaah Fenomena Pendidikan Di Indonesia Dari Pelbagai Disiplin Ilmu. Mitra Mandiri Persada.

[9] Nilmayani, N, Z., \& Risma, D. (2017). Pengaruh Penggunaan Media Busy Book Terhadap Kemampuan Membaca Permulaan Pada Anak Usia 5-6 Tahun Di PAUD Terpadu Filosofia Kubu Babussalam Rokan Hilir.

[10] Organization, W. H. (1997). Life Skills Education For Children and Adolescents In Schools.

[11] Utomo, I. A., \& RamliFuraidah, M. (2018). Penerapan Strategi Bermain melalui Media Busy Book untuk Meningkatkan Fisik Motorik Halus Anak Usia Dini. Jurnal Pendidikan, 3.

[12] Wijaya, B. (2020). Islamic Montessori Pendidikan Anak di Rumah Berbasis Aktivitas Islami. Pustaka Al Uswah.

[13] Yulianto, T. (2018). Efektivitas Media Pembelajaran Busy Book Terhadap Kemampuan Motorik Halus Anak Dengan Hambatan Majemuk Kelas X Di SLB Negeri 1 Bantul. Jurnal Widia Ortodidaktika, 7.

[14] Zahira, Z. (2019). Islamic Montessori Inspired Activity. Bentang Pustaka. 